\title{
COMPARATIVE STUDY OF THE FLAVONOIDS FROM CHROZOPHORA ROTTLERI (GEIS) JUSS EX SPRENG AND CHROZOPHORA PROSTRATA DALZ \& GIBS
}

\section{VILAS TULSHIRAM NARWADE}

Department of Botany, Bahirji Smarak Mahavidyalaya, Basmathnagar Dist. Hingoli, Maharashtra, India

\begin{abstract}
Flavonoids play an important role in plants as pigmentation and defence. They also show as antioxidant, antibacterial, anti-tumour and anti-inflammatory activities. Due to the above importance, the present study was taken for the identification, detection and also comparison between Chrozophora rottleri (Geis) Juss ex Spreng and Chrozophora prostrata Dalz \& Gibs (Euphorbiaceae). Flavonoids from Chrozophora rottleri and Chrozophora prostrata, each plant stem and leaves was used separately and was extracted through Paper Chromatography (P.C.) method with using different solvents. Each flavonoid was identified and detected by measuring $R_{f}$ value with using absorption spectra. Plants flavonoids were recorded, these recorded flavonoids were anthocyanidins, glycosides, flavones and flavonols and they were comparatively studied. From the result, Cyanidin (Anthocyanidin) and Apigenin (Flavone) are commonly observed in C. rottleri and C. prostrata but other flavonoids show different colour pigments, $R_{f}$ values and absorption spectra which were recorded as dissimilar in chemical nature.

KEYWORDS C. rottleri, C. prostrata, PC, Flavonoids, spectroscopy
\end{abstract}

Received: Oct 30, 2020; Accepted: Nov 20, 2020; Published: Dec 26, 2020; Paper Id.: IJBRDEC202010

\section{INTRODUCTION}

Plants flavonoids play an important role for colour pigmentation and defence mechanisms. These are polyphenolic and biological active compounds. Flavonoids are widely present in plants and they are found in the cell vacuoles as glycosides. Flavonoids show antioxidant in reducing cancer risk (Block, 1992), risk of coronary heart diseases (Hertog et al, 1993), antimicrobial activity (Cushnie TPT et al, 2005) and antifungal activity (Galeotti F; et al 2008). Flavonoids are classified into many sub groups namely, viz., anthocyanidins, glycosides, flavones, flavonols etc. Anthocyanidins like Cyanidin and Delphinidin inhibit epidermal growth factor receptor in cancer cells (Acquaviva R. et al, 2003) while Malvidin is less effective. Flavones and flavonols are collectively known as anthoxanthin. Anthoxanthins are yellow colour pigments. They are widely distributed in petals and leaves of higher plants. The highly hydroxyl flavones such as Apigenin and Chrysoeriol which occur in plants possess a number of medicinal values. Apigenin shows anti-tumour properties (Jing Fang et al, 2009) and pharmaceutical interest in relation to inhibit anti-oestrogen resistant breast cancer cell growth (Long $X$ et al, 2008). It also shows potent inhibitor of CYP2C9 in the body (Si Dayong et al, 2009). Chrysoeriol shows antioxidant and anti-inflammatory properties (Moscatelli V et al, 2006). Flavonols like Gossypetin shows antibacterial activity (Mounnissamy VM et al, 2002). Chrozophora rottleri (Geis.) Juss ex Spreng (Euphorbiaceae) is branched herbs, leaves 3-lobed, truncate, chordate, wrinkled and rugose with deep seated nerves, stellate, tomentose on both surfaces and flower in terminal, densely 
stellate hairy racemes and found on black cotton soil.

Chrozophora prostrata Dalz \& Gibs (Euphorbiaceae) is prostrate, stellate hairy herb, branches red, leaves ovate or orbicular, red-brown, truncate, plicate, hoary, tomentose, beneath, petals yellow and found in cultivated field, river banks and drying ditches. These plants are also the major sources of their flavonoids. Such plants are neglected as to weeds. Hence the present study was undertaken to identification and comparison of flavonoids in these plants.

\section{MATERIALS AND METHODS}

Chrozophora rottleri and Chrozophora prostrata were collected from cultivated field of Basmathnagar Dist. Hingoli (M.S.), India. These plants were identified on the basis of morphology and were made Herbarium which was stored in Botany Laboratory, Adarsh College, Hingoli.

\section{PREPARATION OF PLANT EXTRACT (each plant separate)}

\section{I Glycosides}

Chrozophora rottleri and Chrozophora prostrata, each plant stem and leaves was taken and separately dried in Oven at $50^{\circ} \mathrm{C}$. Each dried material was collected and treated with boiling alcohol at $90^{\circ} \mathrm{C}$ for few minutes. Then this treated material was filtered through Whatman filter paper No.3. Each filtrate was taken and concentrated by Rotary vacuum evaporator (R. V. E.) at $40^{\circ} \mathrm{C}$. The concentrated filtrate of each species was again treated with Petroleum ether to avoid latex. The latex free extract was taken and treated with diethyl ether to separation of catechin and cinnamic acid. Catechin and Cinnamic acid free extract was concentrated in R. V. E. This concentrated extract was treated with Ethyl acetate to remove flavonols and flavones. Then Ethyl acetate layer was formed and this layer was discarded. Ethyl acetate free extract was concentrated in R. V. E. The concentrated material was dissolved in Methanolic $\mathrm{HCl}$ which was taken in 97:3ratio. The obtained mixture was blended and centrifuged at $2000 \mathrm{Rpm}$ for 3 minutes to formation of supernatant. This supernatant was concentrated by using of R. V. E. at $40^{\circ} \mathrm{C}$. This concentrated material of each plant was taken and spotted on the proper site of Paper chromatography (PC) for identification of glycosides. These glycosides were separated using $\mathrm{BuHCl}$ solvent and $1 \% \mathrm{HCl}$ solvent system. The $R_{f}$ value of each glycoside was measured.

\section{II Anthocyanidins}

From glycosides extract preparation method was also using for same preparation of supernatant of each plant. The obtained supernatant was used for identification of anthocyanidins. This obtained supernatant was treated with $2 \mathrm{M} \mathrm{HCl}$ and it was boiled at $50^{\circ} \mathrm{C}$ for 40 minutes. Then the small volume of isoamyl-alcohol was taken and in it dissolved the small amount of this boiled supernatant and it was concentrated in R. V. E. Then isoamyl-alcohol solution was spotted on the proper site of PC. Each plant spotted PC papers were dried and used Forestal solvent and Formic acid solvent in 3:30:10 and 2:5:3 ratios, respectively for separation of compounds. Each compounds $R_{f}$ value was measured and calculated for identification of anthocyanidins.

\section{III Flavonols and flavones}

As per glycosides procedure up to concentrated the diethyl ether extract was again prepared for identification of flavonols and flavones. The prepared diethyl ether extract of each plant was taken separately. This extract free from Cinnamic acid and catechin, it was concentrated in R. V. E. Then the concentrated extract was treated with $2 \mathrm{M} \mathrm{HCl}$ and it was boiled at $100^{\circ} \mathrm{C}$ in Oven for 40 minutes. This boiled extract was again concentrated through R. V. E. Then the concentrated extract 
was taken and treated with Ethyl acetate. Ethyl acetate extract was concentrated up to dryness. The small volume of Ethanol was taken and in it dissolved the small amount of dried residue. The prepared Ethanolic solution was spotted on the proper site of PC papers. Each plant spotted PC paper was dried and using different solvent systems for separation of these compounds. These systems were $\mathrm{BAW}, \mathrm{PhOH}$ and Forestal solvent in 4:1:5, 3:1 and 3: 30:10 ratios, respectively. Each PC paper was used for each solvent, separately. Each flavonols and flavones compound were identified by the using of UV light with fuming of Ammonia. Each compound colour was observed, measured and calculated the $R_{f}$ value.

\section{SPECTRAL ANALYSIS (each plant separate)}

\section{I Anthocyanidins:}

Each colour compound from each PC was taken and it was eluted in the solution contained water, Methanol and Acetic acid $(25: 70: 5 \mathrm{v} / \mathrm{v})$. This solution was continued till the paper become colourless. Then each obtained mixture was filtered through Whatman filter paper, separately. Each filtrate was taken and concentrated through R. V. E. with using desiccators to formed dried residue. Then Methanol containing $1 \% \mathrm{HCl}$ was taken and in it dissolved the dried residue. This obtained Methanolic solution was used for spectroscopic analysis. The absorption spectra of each solution was recorded in the region of $450-600 \mathrm{~nm}$.

\section{II Flavonols and Flavones}

Each band from PC paper was separated and it was dissolved in 95\% Ethanol in dark at room temperature, separately for each plant as well as each band. This Ethanolic solution from each band was filtered by Whatman filter paper. Each filtrate was used for spectroscopic identification for flavonols and flavones. This filtrate was scanned in addition with the trace amount of $\mathrm{AlCl}_{3}$, Sodium ethoxide and Sodium borohydrate which were used for colouration. The absorbed visible spectrum was recorded in the region of 268-386 $\mathrm{nm}$.

Table 1: Comparative studied Glycosides (flavonoids) from Chrozophora rottleri (Geis.) Juss ex Spreng and

Chrozophora prostrata Dalz \& Gibs were observed on the basis of visible colours and measured $\boldsymbol{R}_{f}$ values

\begin{tabular}{|c|c|c|c|c|c|}
\hline \multirow{2}{*}{$\begin{array}{l}\text { Sr. } \\
\text { No. }\end{array}$} & \multirow{2}{*}{$\begin{array}{l}\text { Name of the } \\
\text { plant }\end{array}$} & \multirow[t]{2}{*}{ Visible colour } & \multicolumn{2}{|c|}{$R_{f}$ value (x 100) in } & \multirow[t]{2}{*}{ Glycosides } \\
\hline & & & BuHCl & $1 \% \mathrm{HCl}$ & \\
\hline \multirow[t]{2}{*}{1} & \multirow[t]{2}{*}{$\begin{array}{l}\text { Chrozophora } \\
\text { rottleri }\end{array}$} & Dull orange yellow & -- & 73 & 3-Sophoroside 7-glucoside (Pelargonidin) \\
\hline & & $\begin{array}{ll}\text { Intense } & \text { yellow } \\
\text { fluorescent }\end{array}$ & 41 & -- & 3-Deoxyanthocyanidins 5-glucoside \\
\hline \multirow[t]{2}{*}{2} & \multirow[t]{2}{*}{$\begin{array}{l}\text { Chrozophora } \\
\text { prostrata }\end{array}$} & Dull purple & 67 & -- & Guineesin (Petunidin) \\
\hline & & Dull magenta & -- & 54 & 3-Sophoroside 5-glucoside (Cyanidin) \\
\hline
\end{tabular}


Table 2: Comparative studied Anthocyanidins (flavonoids) from Chrozophora rottleri (Geis.) Juss ex Spreng and Chrozophora prostrata Dalz \& Gibs were observed on visible colours, $R_{f}$ values and absorption spectra

\begin{tabular}{|c|c|c|c|c|c|c|}
\hline \multirow{2}{*}{$\begin{array}{l}\text { Sr. } \\
\text { No. }\end{array}$} & \multirow[t]{2}{*}{ Name of the plant } & \multirow{2}{*}{$\begin{array}{l}\text { Visible } \\
\text { colour }\end{array}$} & \multicolumn{2}{|c|}{$R_{f}$ value (x 100) in } & \multirow{2}{*}{$\begin{array}{l}\text { Visible max. in } \\
\text { MeOH-HCl } \lambda \text { max. }\end{array}$} & \multirow[t]{2}{*}{ Anthocyanidins } \\
\hline & & & Forestal & $\begin{array}{l}\text { Formic } \\
\text { acid }\end{array}$ & & \\
\hline \multirow[t]{3}{*}{1} & \multirow{3}{*}{$\begin{array}{l}\text { Chrozophora } \\
\text { rottleri }\end{array}$} & Purple & 46 & -- & 543 & Petunidin \\
\hline & & Red & 68 & 33 & 520 & Pelargonidin \\
\hline & & Magenta & -- & 22 & 535 & Cyanidin \\
\hline \multirow[t]{2}{*}{2} & \multirow[t]{2}{*}{$\begin{array}{l}\text { Chrozophora } \\
\text { prostrata }\end{array}$} & Purple & 60 & -- & 542 & Malvidin \\
\hline & & Magenta & -- & 22 & 535 & Cyanidin \\
\hline
\end{tabular}

Table 3: Comparative studied Flavonols and flavones (Flavonoids) from Chrozophora rottleri (Geis.) Juss ex Spreng and Chrozophora prostrata Dalz \& Gibs were observed on the basis of colours, calculated $\boldsymbol{R}_{f}$ values and recorded spectra

\begin{tabular}{|c|c|c|c|c|c|c|c|c|}
\hline \multirow{2}{*}{$\begin{array}{l}\text { Sr. } \\
\text { No. }\end{array}$} & \multirow{2}{*}{$\begin{array}{c}\text { Name of the } \\
\text { plant }\end{array}$} & \multirow{2}{*}{$\begin{array}{l}\text { Colour in } \\
\mathrm{UV}+\mathrm{NH}_{3}\end{array}$} & \multicolumn{3}{|c|}{$R_{f}$ value (x 100) in } & \multirow{2}{*}{$\begin{array}{l}\text { Spectral } \\
\text { max. in } \\
\text { EtOH } \\
\text { (nm) }\end{array}$} & \multirow[t]{2}{*}{ Flavonols } & \multirow[t]{2}{*}{ Flavones } \\
\hline & & & Forestal & BAW & PhOH & & & \\
\hline 1 & C. rottleri & Dull Ochre & 83 & 89 & -- & 336 & --- & Apigenin \\
\hline \multirow[t]{4}{*}{2} & \multirow[t]{4}{*}{ C. prostrata } & Dull Ochre & 83 & -- & -- & 336 & --- & Apigenin \\
\hline & & Yellow & -- & 82 & -- & 350 & --- & Chrysoeriol \\
\hline & & Dull Black & -- & -- & 12 & 278 & Gossypetin & --- \\
\hline & & $\begin{array}{l}\text { Fluorescent } \\
\text { yellow }\end{array}$ & -- & -- & 50 & 369 & Azaleatin & --- \\
\hline
\end{tabular}

\section{RESULT}

Flavonoids of Chrozophora rottleri (Geis.) Juss ex Spreng and Chrozophora prostrata Dalz \& Gibs. were observed and identified on the basis of visible colours, measured $R_{f}$ values and recorded spectra. These flavonoids were observed as glycosides, anthocyanidins, flavonols and flavones. Glycosides of C. rottleri were recorded as 3-sophoroside 7-glucoside (Pelargonidin) and 3-Deoxyanthocyanidins 5-glucoside were observed and identified as dull orange yellow colour in 1\% $\mathrm{HCl}$ solvent and other an intense yellow fluorescent colour was shown in $\mathrm{BuHCl}$ solvent. Both visible colours measured and calculated of these $R_{f}$ values of dull orange yellow was 73 and intense yellow fluorescent was recorded as 41 (from Table 1). In C. prostrata, glycosides were also recorded as 3-sophoroside 5-glucoside (Cyanidin) and Guineesin (Petunidin) which were identified on the basis of visible colours through PC and were observed as dull magenta (Cyanidin glycoside) and dull purple (Petunidin glycoside) in colours.. The $R_{f}$ value of each glycoside was measured and calculated. These $R_{f}$ values were obtained from $\mathrm{BuHCl}$ solvent as 67 (Guineesin) and 54 (3-sophoroside 5-glucoside) in $1 \% \mathrm{HCl}$ 
solvent systems (from Table 1). Identified anthocyanidins from C. rottleri were observed on the basis of visible colours from PC papers and $R_{f}$ values and also absorption spectra. Pelargonidin was observed as red colour in Forestal and Formic acid solvents and it measured $R_{f}$ values from these solvents were 68 and 33, respectively. Petunidin was purple in Forestal solvent and it $R_{f}$ value was measured as 46 . The visible colour of Cyanidin was observed in Formic acid solvent as magenta and it $R_{f}$ value was measured as 22. The absorption spectra were recorded as $520 \mathrm{~nm}$ (Pelargonidin), $543 \mathrm{~nm}$ (Petunidin) and $535 \mathrm{~nm}$ (Cyanidin). But in C. prostrata, the visible colours of anthocyanidins were observed as purple and magenta. The purple colour was measured and calculated the $R_{f}$ value from PC as 60 (Malvidin) in Forestal solvent. Cyanidin was observed as magenta colour and it $R_{f}$ value was measured as 22 in Formic acid solvent. The observed spectra were recorded as $542 \mathrm{~nm}$ (Malvidin) and $535 \mathrm{~nm}$ (Cyanidin). Cyanidin was recorded from both plants in the same solvent (Formic acid). Pelargonidin was observed in $C$. rottleri which was recorded from both solvents (Forestal and Formic acid). In $C$. prostrata, Malvidin was recorded but Pelargonidin was not observed in both solvent systems. Petunidin and Malvidin were not observed in Forestal solvent (Table 2).

Flavonols were not recorded from $C$. rottleri in $\mathrm{BAW}, \mathrm{PhOH}$ and Forestal solvents but these were observed in $C$. prostrata as dull black and fluorescent yellow colours under UV light with fuming of ammonia. The dull black colour was measured from PC and the $R_{f}$ value was calculated as 12 (Gossypetin) in PhOH solvent. The $R_{f}$ value of fluorescent yellow colour was also measured and calculated from PC as 50 (Azaleatin) in PhOH solvent system. But these flavonols were not recorded in BAW and Forestal solvents. The absorption spectrum of each flavonol was recorded as $278 \mathrm{~nm}$ (Gossypetin) and $369 \mathrm{~nm}$ (Azaleatin). Flavones like Chrysoeriol and Apigenin were recorded in BAW and Forestal solvents but these flavones were not observed in $\mathrm{PhOH}$ solvent system. Flavones were also recorded from C. rottleri and C. prostrata. These recorded flavones were observed as dull ochre and yellow colour under UV light with fuming of ammonia. In both plants, the dull ochre colour was observed and measured $R_{f}$ value from PC as 83 from Forestal solvent. But this colour was also observed in $C$. rottleri from BAW solvent and it $R_{f}$ value was calculated from PC as 89 (Apigenin). The yellow colour was recorded from $C$. prostrata but it was not observed in $C$. rottleri. Yellow colour was measured and calculated from PC and the recorded $R_{f}$ value was 82 (Chrysoeriol) in BAW solvent. But Chrysoeriol was not recorded from $C$. rottleri and it was also not observed in Forestal and $\mathrm{PhOH}$ solvents. The absorption spectrum of Apigenin was recorded as $336 \mathrm{~nm}$ and 350 nm of Chrysoeriol from Ethanolic solution (Table 3).

\section{CONCLUSIONS}

From the results of present study observation shows that glycosides, anthocyanidins, flavonols and flavones are recorded from $C$. rottleri and C. prostrata. Flavonols are observed in C. prostrata only but these are not observed in $C$. rottleri. So this stand, it may be concluded that each identified flavonoids shows different visible colour, $R_{f}$ value and absorption spectrum. These plants flavonoids are not similar in proportion but Cyanidin (Anthocyanidin) and Apigenin (Flavone) are commonly recorded from both plants. So that it also focuses on the plant taxonomists and chemo-taxonomists perspective because most of the plants show similar in morphology but they are rarely similar in chemical nature. $C$. rottleri and $C$. prostrata are neglected as weeds but they contain a polyphenolic compounds i.e. flavonoids. Plants flavonoids are used in medicine to control of different microbial, fungal and cancer diseases and they are also protected to heart. So these undesired plants contain flavonoids which are beneficial to mankind. 


\section{REFERENCES}

1. Acquaviva $R$, Russo A, Galvano $F$, et al. cyanidin and cyanidin 3-o-beta-D-glucoside as DNA Cleavage protestors and antioxidants. Cell Biol Toxicol.2003; 19(4):243-252.

2. Block, G., 1992. The data support a role for antioxidant in reducing cancer risk. Nutr. Rev., 50:207-213.

3. Cushnie TPT, Lamb A. J., 2005. Antimicrobial activity of flavonoids. International Journal of Antimicrobial Agents 26 (5): 343-356.

4. Dimajo D, Giammanco M, Tripoli E, Giammanco S and Finotti E, 2005, Flavanonesin Citrus fruit: Structure-antioxidant activity relationships. Food Res. Intern., 38:1161-1166.

5. Galeotti F; Barile E; Curir P; Dolci M; Lanzotti V, 2008. Flavonoids from carnation (Dianthus caryophyllus) and their antifungal activity. Phytochemistry Letters 1:44. Doi. Lancet, 342:1007-1011.

6. Hartwig UA, Maxwell CA, Joseph CM, Phillips DA (1990). “Chrysoeriol and luteolin Released from Alfalfa Seeds Induce nod Genes in Rhizobium meliloti." Plant Physiol 92(1):116-122.

7. Hertog M.G.L., Feskeens E.J.M., Holmann C.H., Katan M.B. and Kromhout D. (1993). Dietary antioxidant flavonoids and risk of coronary heart diseases. The Zutphen elderly study. Lancet, 342:1007-1011

8. Jing Fang, Qiong Zhou, Ling-Zhi Liu, Chang Xia, Xiaowen Hu, Xianglin Shi, Bing-Hua Jiang (2006). Apigenin inhibit tumour angiogenesis through decreasing HIF-1a and VEGF expression: Apigenin significantly inhibited tumour angiogenesis in vivo. Oxford Journals Carcinogenesis pp-858-864.

9. Long X, Fan M, Bigsby RM, Nephew KP (2008). “Apigenin inhibit antiestrogen-resistant breast cancer cell growth through oestrogen receptor-alpha-dependent and oestrogen receptor-alpha-independent mechanisms." MolCancer Ther 7(7):20962108 .

10. Si D, Wang Y, Zhou YH et al, 2009. Mechanism of CYP2C9 inhibition by flavones and flavonols. Drug Metab. Dispos. 37 (3):629-34

11. Moscatelli V, Hnatyszyn O, Acevedo C, Megias J, Alcaraz MJ \& Ferraro G (2006). "Chrysoeriol is a flavonoid with antioxidant and anti-inflammatory properties." J Mol. Cell Cardiol 20066:41:389-405.

12. Mounnissamy VM; Kavimani S; Gunasegaran R. Antibacterial activity of Gossypetin isolated from Hibiscus sabdaritfa. The Antiseptic. 2002 Mar; 99(3): 81-2

13. Ayangla, N. W., N. E. E. T. U. Singh, and A. J. A. Y. Kumar. "Phytochemical analysis of plant species of genus Zanthoxylum." International Journal of Medicine and Pharmaceutical Science 6.1 (2016): 1-8.

14. GHANIA, IAZZOURENE, MOUHOUCHE FAZIA, and HAZZIT MOHAMED. "ANTIOXYDANT AND INSECTICIDAL ACTIVITY OF ALGERIAN MYRTUS COMMUNIS L. EXTRACTS." International Journal of Agricultural Science and Research (IJASR) 4.6 (2014): 193-201.

15. Sudha, K., et al. "Evaluation of functional properties of Hylocereus undatus (White dragon fruit)." International Journal of Agricultural Science and Research 7.5 (2017).

16. Sankar, AS SUMAN, N. V. Sugathan, and M. A. D. H. U. R. I. Mohan. "A REVIEW ON SYNERGISTIC AND HORMETIC ACTION OF SWERTIA CHIRATA FROM HOMOEOPATHIC PERSPECTIVE." International Journal of AYUSH Medicine \& Research (2017): 2456-6209. 